\title{
THE STERN ART LIBRARY
}

\author{
BY JAMES STUBBLEBINE
}

Professor Stubblebine is the Chairman of the Rutgers University Department of Art.

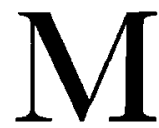

R. Louis E. Stern was an important connoisseur of modern art, having in his collection several hundred masterpieces of the nineteenth and twentieth centuries, not to mention one of the very great collections of fine, illustrated books. During the thirty or so years in which he collected his pictures, Mr. Stern also brought together a sizeable library of books dealing with the artists and the art movements which were represented in his collection. Upon his death, a Foundation consisting of five friends was designated by the terms of his will to dispose of his collections among existing museums or institutions operated for educational purposes and the encouragement of art. As a result, the collection of paintings has gone to the Philadelphia Museum of Art, the illustrated books to the Museum of Modern Art in New York and the art library, consisting of approximately three thousand volumes, has come to Rutgers University.

The books in the Stern Library cover an extraordinary range of nineteenth and twentieth century painting, graphics, and sculpture, principally, of course, French art in which Mr. Stern's collection was strongest. The Romantic Period is well represented with a dozen definitive books on Delacroix, as well as important works on Gros, Gericault, Chasseriau and Daumier. Impressionism and Post-Impressionism are similarly well-represented. The measure of his enthusiasm for the paintings of particular artists and periods is often reflected in the number of volumes pertaining to them; there are, for example, about fifteen volumes each on Courbet, Manet, Renoir and Seurat, about twenty-five volumes each on Cezanne and Matisse, and over fifty volumes on Picasso. Almost always his library includes the fundamental monographs. Thus, on Degas there is the four volume catalog by Lemoisne, as well as the Rouart and the Lafond. On Redon's graphic work there are the two books of Mellerio as well as the Sandstrom. The Cezanne bibliography includes the 
Venturi catalog and two books of drawings edited by Chappuis, among several important works. The more than twenty works on van Gogh include the important de la Faille.

While this collector's interests reflect a modern taste, it is revealing to discover the number of volumes on such artists as Michelangelo and Leonardo, or, for instance, the six volume catalog of Rembrandt's drawings by Benesch. There are, furthermore, a considerable number of books on the art of such early epochs as, for example, Egypt and the Ancient Near East.

One of Mr. Stern's close friends for a number of years was Marc Chagall and Mr. Stern's collection of Chagall includes ten paintings and sixteen illustrated books besides over twenty volumes about the artist. All of these various works were gathered together in a special room of his New York home, a room which was called the Chagallery.

The library is further rounded out by an excellent collection of periodicals, including l'Oeil, Tiger's Eye, xxe siècle, Art d'Aujourd'hui. Finally, a great number of exhibition catalogs are included.

The Stern Library will be of enormous benefit to the expanding program of Art History study at the University. It will be housed with the existing art book collection in Voorhees Hall in a new art library facility, probably by i 966 , at which time the Voorhees building will be in use as an art center. It is expected that a master's degree in art history will also be instituted in 1966. The gift of the Stern Library adds great impetus to research in the history of modern art at the University; without doubt the principal research in the graduate program will be conducted in the area of modern art for some time to come.

Mr. Stern was born in Russia and came to America as a small boy. Before moving to New York City he lived for many years in New Jersey; raised in Atlantic City, he attended Vineland High School. It is altogether fitting that his remarkable collection of books should find a permanent home at the University of the state which nurtured him for many years. 